\title{
Hubungan Kualitas Batubara terhadap Kedalaman pada Lapisan Batubara Seam A20 daerah Merandai Kotamadya Samarinda Kalimantan Timur
}

\author{
Widodo \\ Program Keahalian Geologi Pertambangan, SMK Negeri 1 Balikpapan \\ Jalan Marsma Iswahyudi Balikpapan email : widodoyuni2002@yahoo.co.id \\ Totok Sulistyo \\ Jurusan Teknik Sipil Politeknik Negeri Balikpapan \\ Jl. Sukarno, Hatta Km.8, Balikpapan email: totok.sulistyo@ poltekba. ac.id
}

\begin{abstract}
Administratively, the research area is part of P.T. Bukit Baiduri Energi in Samarinda City and Kutai Kertanegera Regency, East Kalimantan province with latitute and longitude 117³ '59.76" - 117\%6'28.80" BT and $0^{\circ} 180^{\prime} 00^{\prime \prime}-0^{\circ} 360^{\prime} 00^{\prime \prime}$ LU. This area is part of Kutai Basin that was formed before Eocene. Based on outcrop, cutting and coring, the coal seam A20 are identified as: dark black, compact, massif, brittle, cleat, an contain resine. seam thickness between 9.75-13.16 m.

The heterogeneity of coal quality like calorific value, fix carbon, total sulfur, volatile matter, ash and moisture in every seam is difference according to their depth. Relationship of coal quality and its depth, can be analyzed with statistical analyze approach. The result of the analysis can be used for further exploration and exploitation strategy.

The statistical analysis using computer software will let us to know the relationship of seam A20 quality ( $C V, T S, F C, V M$, Ash and $M)$ and its depth simple correlation and regression are found that in every bore hole gives fluctuative result and it has signification of individual parameter seam quality its depth.

Meanwhile the result of double correlation and regression, all parameters of the seam A20 quality with its depth in all drill holes show that the stratigraphic position has very strong corelation and signification with seam quality. Even though, depth position of seam A20 contribute $84.90 \%$ for drill hole KP2N-380, 86.10\% for drill hole KP2N392 and $88.80 \%$ for drill hole KP2N-397 to quality of seam, and the rest is influenced by geological factors.
\end{abstract}

Keyword: Coal Seam, Depth, Quality

\begin{abstract}
Abstrak
Secara adimistratif daerah penelitian terletak di wilayah konsesi PT. Bukit Baiduri Energi di Kecamatan Samarinda dan Kabupaten Kutai Kartanagara, Provinsi Kalimantan Timur. Secara geografis terletak pada kordinat 117³'59.76” - 117\%6'28.80” BT dan 0¹80 '00” - 0³60'00” LU.Daerah ini merupakan bagian dari Cekungan Kutai yang terbentuk sebelum Eosen. Berdasarkan data singkapan, cutting dan corring yang diperoleh, seam A20 bercirikan berwarna hitam, kompak, massif, britle, cleat, mengandung dammar, ketebalan berkisar 9.75-13.16 m.

Heterogenitas kualitas batubara baik kandungan kalori, debu, kelembaban, sulfur dan lain sebagainya di tiap seam/lapisan batubara berbeda di tiap kedalaman. Untuk mengetahui hubungan kualitas batubara terhadap kedalaman lapisan seam A20 dianalisis melalui pendekatan analisa statistika. Hasil analisa tersebut dapat digunakan dalam ekplorasi lebih lanjut dan strategi eksploitasi.

Hasil perhitungan statistik dengan menggunakan perangkat komputer untuk mengetahui hubungan kualitas seam A20 (CV, TS, FC, VM, Ash dan M) terhadap kedalaman seam A20 dengan menggunakan korelasi dan regresi sederhana diperoleh bahwa setiap lokasi titik bor memberikan hasil yang fluktuatif dalam hal hubungan dan signifikansi secara individu masing-masing parameter kualitas seam terhadap kedalaman batubara.

Sementara itu hasil korelasi dan regresi ganda/secara bersama-sama semua parameter kualitas seam A20 terhadap kedalaman nya, di semua titik bor diperoleh bahwa secara simultan/bersama-sama kedalaman seam mempengaruhi kualitas batubara. Bahkan kontribusi kedalaman memberikan pengaruh sangat kuat dan signifikan secara langsung $84.90 \%$ di titik bor KP2N-380, 86.10\% di titik bor KP2N-392 dan 88.80\% di titik bor KP2N-397 terhadap kualitas batubara seam dan sisanya dipengaruhi oleh faktor geologi lainnya. Kata kunci :Seam Batubara, Kedalaman, Kualitas.
\end{abstract}




\section{Pendahuluan}

Lapisan batubara yang terdapat di Cekungan Kutai merupakan endapan non marin dari transgresi pre-marin dalam cekungan antar pegunungan. Tatanan geologi suatu cekungan tersebut sangat berpengaruh terhadap pembentukan lapisan batubara. Pengaruh tatanan geologi ini berakibat pula terhadap kualitas dari suatu lapisan batubara.

Lapisan batubara/seam A20 di daerah wilayah tambang P.T. Bukit Baiduri Energi di Merandai Samarinda Kalimantan Timur terdapat dalam Cekungan Kutai.

Penyebaran suatu kualitas batubara baik kandungan kalori, debu, kelembaban, sulfur dan lain sebagainya di tiap seam/lapisan batubara berbeda pada tiap kedalaman. Untuk mengetahui hubungan kualitas batubara terhadap kedalaman seam/lapisan batubara dapat dianalisis melalui pendekatan analisa statistika.

Secara adimistratif daerah penelitian termasuk ke dalam wilayah Kecamatan Samarinda Hulu, Kodya Samarinda dan Kecamatan Loa Janan, Kabupaten Kutai Kartanagara, Provinsi Kalimantan Timur. Secara geografis lokasi daerah penelitan terletak di wilayah tambang batubara P.T. BBE terletak pada $117^{\circ} 3$ '59.76" sampai dengan $117^{\circ} 6^{\prime} 28.80^{\prime \prime}$ BT dan $0^{\circ} 180^{\prime} 00^{\prime \prime}$ sampai dengan $0^{\circ} 360^{\prime} 00^{\prime}$ " LU (Gambar 1). Kualitas batubara dapat ditentukan dengan analisis laboraturium melalui analisis proksimat dan analisis ultimat. Parameterparameter yang sering menjadi acuan dalam menentukan kualitas batubara adalah (ASTM, 1981, op cit Wood et al., 1983): Kalori (Calorific Value), Kadar kelembaban (Moisture), Zat terbang (Volatile Matter), Kadar abu (Ash content), Ukuran (Coal size) ketergerusan (Hardgrove Grindability Index atau HGI). Secara umum kualitas lapisan batubara/seam dipengaruhi oleh banyak faktor geologi. Salah satu faktor geologi yang mempengaruhi kualitas batubara adalah posisi kedalaman lapisan/seam batubara itu sendiri (Braunstein, H.M., 1981).
Kajian ini akan bermanfaat untuk mengetahui pengaruh kedalaman terhadap kualitas batubara/seam dan untuk menentukan lokasi dimana lapisan batubara/seam memiliki kualitas khusus yang dapat dipertimbangan untuk blending.

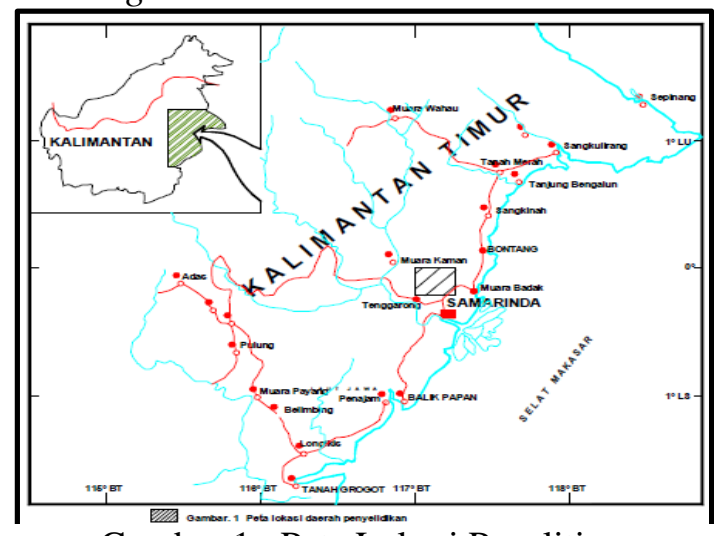

Gambar 1. Peta Lokasi Penelitian

\section{Metoda Penelitian}

Metode yang digunakan adalah observasi lapangan yang meliputi observasi hubungan lapisan/seam batubara terhadap lapisan batuan di atas maupun di bawahnya dan kondisi (pengaruh) lapisan batuan yang mengapit seam batubara tersebut. Kemudian dilakukan crosscheck data lapangan dengan data hasil pemboran yaitu log bor. Hasil crosscheck lapangan dikorelasikan dengan data bor untuk mengetahui posisi secara vertikal dari penyebaran seam. Data kualitas dan lainnya dari beberapa titik bor berasal dari hasil coring. Kemudian data kualitas batubara seam dianalisis secara satistik untuk mengetahui hubungan penyebaran dan/atau kedalaman dengan kualitas, serta faktor geologi yang ada.

Penelitian ini dilakukan melalui tahap pendahuluan yang terdiri dari studi pustaka dan peninjauan lapangan. Tahap selanjutnya adalah pengambilan Data, yang terdiri dari: data sekunder, data geologi permukaan, dan data bor seam A20 serta kualitas seam A20 
tiap titik bor terpilih. Tahap berikutnya pengolahan data dan analisis, yang meliputi : 1) analisis data singkapan batubara, 2) crosscheck data lapangan dengan log bor, 3) korelasi seam A20 batubara antar lubang bor, 4) analisis statistik kualitas batubara, 5) analisis hubungan kedalaman dan kualitas batubara seam A20. Dan dilakukan penarikan kesimpulan

\section{Hasil Penelitian dan analisis data}

Sampel batubara yang diambil berjumlah 36 buah sampel seam A20 yang berasal dari 3 buah titik bor di Blok KP 2000 North (KP2N). Adapun jarak antar titik bor KP2N 380 dengan titik bor KP2N 397 sejauh 440 m dan jarak titik bor KP2N 380 dengan titik

bor KP2N 392 sejauh $840 \mathrm{~m}$ searah long strike dengan kedalaman yang berbeda dari masing-masing titik bor. Roof seam A20 di titik bor KP2N 380 didapatkan pada kedalaman $11.10 \mathrm{~m}$ dari sea level dengan total depth $70.50 \mathrm{~m}$. Roof seam A20 di titik bor KP2N 392 didapatkan pada kedalaman $34.26 \mathrm{~m}$ dari sea level dengan total depth $58.20 \mathrm{~m}$. Sedangkan roof seam A20 di titik bor KP2N 397 didapatkan pada kedalaman $39.50 \mathrm{~m}$ dari sea level dengan total depth $50.95 \mathrm{~m}$.

Hasil analisa proksimat dari 3 titik bor terpilih ditampilkan pada tabel berikut:

Tabel 1. Hasil Analisa Proksimat Seam A20 Bor KP2N-380

\begin{tabular}{|c|c|c|c|c|c|c|}
\hline \multirow{2}{*}{$\begin{array}{l}\text { Kedalaman } \\
\text { (Dari } \\
\text { Sea Level) }\end{array}$} & \multicolumn{6}{|c|}{ Analisa Proksimat } \\
\hline & C.V adb & T.S & FC & VM & ASH & $M$ \\
\hline ( M ) & (Kcal/kg) & $\begin{array}{l}(\%) \\
\text { adb }\end{array}$ & $\begin{array}{l}(\%) \\
\text { adb }\end{array}$ & $\begin{array}{l}(\%) \\
\text { adb }\end{array}$ & $\begin{array}{l}(\%) \\
\mathrm{adb}\end{array}$ & $\begin{array}{l}(\%) \\
\mathrm{adb}\end{array}$ \\
\hline 11.10 & 5700 & 0.32 & 40.92 & 36.68 & 12.60 & 9.80 \\
\hline 11.58 & 5700 & 0.32 & 40.92 & 36.68 & 12.60 & 9.80 \\
\hline 14.24 & 5568 & 0.16 & 37.28 & 38.17 & 15.69 & 8.86 \\
\hline 15.24 & 6630 & 0.15 & 45.58 & 42.99 & 1.87 & 9.56 \\
\hline 16.24 & 6773 & 0.13 & 45.80 & 44.61 & 0.90 & 8.69 \\
\hline 17.24 & 6732 & 0.12 & 45.22 & 44.34 & 1.37 & 9.07 \\
\hline 18.24 & 6756 & 0.10 & 45.91 & 43.76 & 1.02 & 9.31 \\
\hline 19.24 & 6626 & 0.10 & 45.36 & 43.76 & 1.68 & 9.20 \\
\hline 20.24 & 6610 & 0.10 & 45.12 & 43.88 & 1.87 & 9.13 \\
\hline 21.24 & 6622 & 0.10 & 42.61 & 46.19 & 2.75 & 8.45 \\
\hline 22.24 & 6777 & 0.10 & 45.33 & 44.30 & 1.15 & 9.22 \\
\hline 23.24 & 6652 & 0.13 & 45.26 & 42.72 & 2.15 & 9.87 \\
\hline
\end{tabular}

Tabel 2. Hasil Analisa Proksimat Seam A20

Bor KP2N-392

\begin{tabular}{|c|c|c|c|c|c|c|}
\hline \multirow{2}{*}{ Depth } & \multicolumn{6}{|c|}{ Analisa Proksimat } \\
\hline & $\begin{array}{l}\text { C.V } \\
a d b\end{array}$ & T.S & FC & VM & ASH & M \\
\hline ( M ) & (Kcal/kg) & $(\%)$ & $(\%)$ & $(\%)$ & $(\%)$ & (\%) \\
\hline 34.26 & 6386 & 0.25 & 49.04 & 36.77 & 2.58 & 11.61 \\
\hline 35.26 & 6361 & 0.11 & 47.21 & 37.67 & 5.45 & 9.67 \\
\hline 36.26 & 6559 & 0.10 & 49.19 & 38.34 & 2.11 & 10.36 \\
\hline 37.26 & 6603 & 0.10 & 45.51 & 41.50 & 2.45 & 10.54 \\
\hline 38.26 & 6569 & 0.10 & 46.44 & 41.59 & 1.22 & 10.75 \\
\hline 39.26 & 6613 & 0.10 & 46.75 & 41.56 & 1.29 & 10.40 \\
\hline 40.26 & 6568 & 0.10 & 42.15 & 41.00 & 1.41 & 10.29 \\
\hline 41.26 & 6693 & 0.10 & 43.96 & 44.39 & 2.05 & 9.60 \\
\hline 42.26 & 6911 & 0.10 & 42.22 & 47.30 & 1.75 & 8.73 \\
\hline 43.26 & 6446 & 0.16 & 45.77 & 40.56 & 2.98 & 10.69 \\
\hline 44.26 & 6425 & 0.15 & 44.13 & 41.05 & 5.20 & 9.62 \\
\hline 45.26 & 6674 & 2.24 & 44.31 & 43.64 & 3.93 & 8.12 \\
\hline 46.26 & 6353 & 0.23 & 43.30 & 41.72 & 4.36 & 10.62 \\
\hline
\end{tabular}

Tabel 3. Hasil Analisa Proksimat Seam A20 Bor KP2N-397

\begin{tabular}{|c|c|c|c|c|c|c|}
\hline \multirow{2}{*}{ Depth } & \multicolumn{7}{|c|}{ Analisa Proksimat } \\
\cline { 2 - 7 } & $\begin{array}{c}\text { C.V } \\
\mathrm{adb}\end{array}$ & T.S & FC & VM & ASH & M \\
\hline \multirow{2}{*}{$(\mathrm{M})$} & $\begin{array}{c}(\mathrm{Kcal} / \\
\mathrm{kg})\end{array}$ & $\begin{array}{c}(\%) \\
\mathrm{adb}\end{array}$ & $\begin{array}{c}(\%) \\
\mathrm{adb}\end{array}$ & $\begin{array}{c}(\%) \\
\mathrm{adb}\end{array}$ & $\begin{array}{c}(\%) \\
\mathrm{adb}\end{array}$ & $\begin{array}{c}(\%) \\
\mathrm{adb}\end{array}$ \\
\hline 39.50 & 5980 & 0.48 & 47.22 & 33.62 & 8.49 & 10.67 \\
\hline 40.37 & 5980 & 0.48 & 47.22 & 33.62 & 8.49 & 10.67 \\
\hline 40.93 & 6213 & 0.24 & 46.86 & 36.80 & 5.79 & 10.55 \\
\hline 41.93 & 6496 & 0.11 & 49.59 & 38.41 & 2.20 & 9.80 \\
\hline 42.93 & 6522 & 0.10 & 49.80 & 38.99 & 2.68 & 8.53 \\
\hline 43.93 & 6649 & 0.11 & 49.13 & 40.71 & 1.86 & 8.30 \\
\hline 44.93 & 6671 & 0.11 & 51.07 & 38.47 & 1.35 & 9.11 \\
\hline 45.93 & 6760 & 0.10 & 49.55 & 40.34 & 1.49 & 8.62 \\
\hline 46.93 & 6620 & 0.10 & 47.94 & 41.36 & 2.61 & 8.09 \\
\hline 47.93 & 6354 & 0.12 & 47.95 & 37.96 & 5.02 & 9.07 \\
\hline 48.93 & 6708 & 0.13 & 47.41 & 41.40 & 2.18 & 9.01 \\
\hline
\end{tabular}

Tabel 4. Hubungan Masing-masing Kualitas Batubara ( $C V$, TS, FC, VM, Ash dan $M$ ) Terhadap Kedalaman Seam A20.

\begin{tabular}{|c|c|c|c|c|c|}
\hline $\begin{array}{c}\text { BO } \\
\mathbf{R}\end{array}$ & $\mathbf{Q}$ & $\begin{array}{l}\text { COR. } \\
\text { (Sig.) }\end{array}$ & $\begin{array}{l}\text { COE. } \\
\text { (Sig.) }\end{array}$ & $\begin{array}{c}\text { CTR } \\
\left(\mathbf{R}_{\text {Square }}\right) \\
\end{array}$ & $\begin{array}{c}\text { INTE } \\
\text { PRETASI } \\
\end{array}$ \\
\hline \multirow{6}{*}{ 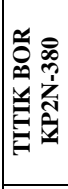 } & $C V$ & 0.002 & 0.005 & $57 \%$ & BK \& S \\
\hline & $T S$ & 0.001 & 0.001 & $67 \%$ & BsK \& S \\
\hline & $F C$ & 0.025 & 0.051 & $33 \%$ & BK \& TS \\
\hline & $V M$ & 0.001 & 0.012 & $62 \%$ & BK \& S \\
\hline & Ash & 0.004 & 0.007 & $53 \%$ & BK \& S \\
\hline & $M$ & 0.195 & 0.390 & $8 \%$ & TB \& TS \\
\hline \multirow{6}{*}{ 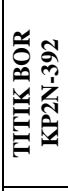 } & $C V$ & 0.310 & 0.621 & $2.3 \%$ & TB \& TS \\
\hline & $T S$ & 0.089 & 0.178 & $15.8 \%$ & TB \& TS \\
\hline & $F C$ & 0.002 & 0.004 & $54.5 \%$ & BK \& S \\
\hline & $V M$ & 0.011 & 0.023 & $38.9 \%$ & BK \& S \\
\hline & Ash & 0.180 & 0.360 & $7.6 \%$ & TB \& TS \\
\hline & $M$ & 0.045 & 0.090 & $23.9 \%$ & BK \& TS \\
\hline \multirow{6}{*}{ 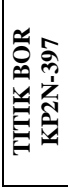 } & $C V$ & 0.005 & 0.011 & $53.5 \%$ & BK \& S \\
\hline & $T S$ & 0.08 & 0.016 & $49.1 \%$ & BK \& S \\
\hline & $F C$ & 0.319 & 0.678 & $2.6 \%$ & TB \& TS \\
\hline & $V M$ & 0.002 & 0.004 & $61.3 \%$ & BK \& S \\
\hline & Ash & 0.021 & 0.042 & $38.4 \%$ & BK \& S \\
\hline & $M$ & 0.005 & 0.010 & $54 \%$ & BK \& S \\
\hline
\end{tabular}




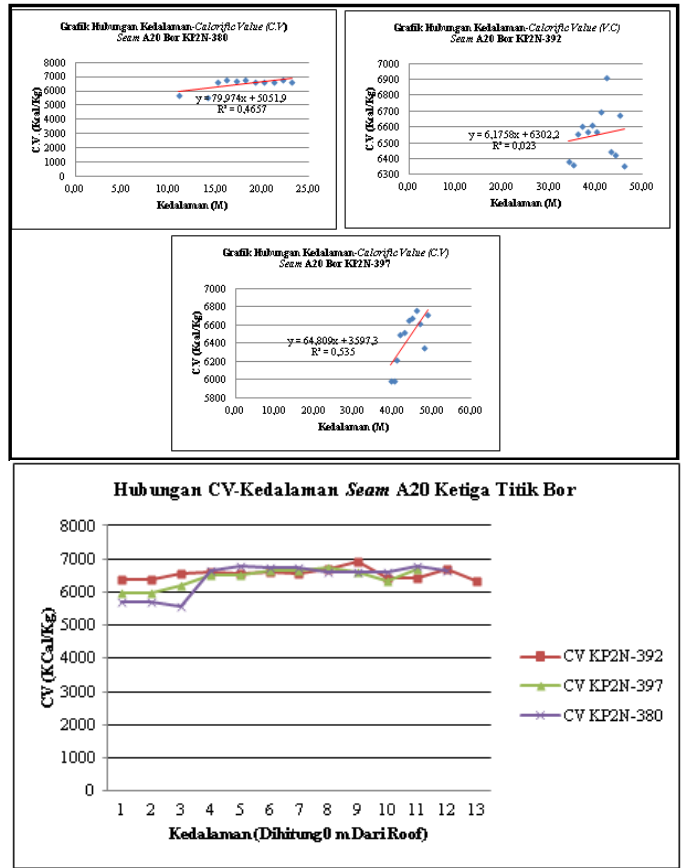

Gambar 2. Grafik Hubungan Calorific ValueKedalaman Seam A20 Grafik pada tiap Bor dan Gabungan Ketiga Bor

Grafik hubungan kedalaman dengan calorivic value batubara seam A20 tampak bahwa trendline $\mathrm{CV}$ terhadap kedalaman di ketiga titik bor KP2N-380, KP2N-392 dan KP2N-397 memperlihatkan semakin dalam posisi batubara maka CV semakin besar. Hasil analisis statistik diperoleh bahwa di kedua titik bor KP2N-380 dan KP2N-397 ada hubungan yang kuat dan signifikan secara langsung bahwa meningkatnya $\mathrm{CV}$ seiring semakin dalamnya batubara seam A20. Artinya bahwa kenaikan $\mathrm{CV}$ ini secara langsung ditentukan oleh kedalaman batubara seam A20 sebesar $57 \%$ di titik bor KP2N 380 dan $53.5 \%$ di titik bor KP2N 397.

Hubungan CV-Kedalaman Seam A20 Ketiga Titik Bor terlihat bahwa nilai rata-rata $\mathrm{CV}$ di ketiga titik bor hampir sama dimana penyebaran nilai $\mathrm{CV}$ di ketiga titik bor hampir berhimpit. Anomali nilai $\mathrm{CV}$ yang lebih rendah dari $\mathrm{CV}$ di titik bor KP2N-392 justru terlihat pada titik bor KP2N-397 di kedalaman $39.50-40.37 \mathrm{~m}$ dan KP2N-380 di kedalaman 11.10 - 14.24 m. Rendahnya nilai CV di kedua titik bor tersebut di atas diakibatkan karena batuan di kedalaman 39.50 - $40.37 \mathrm{~m}$ di titik bor KP2N-397 dan di kedalaman 11.10 - 14.24 m di titik bor KP2N-380 merupakan black shale dan coally shale. Hadirnya parting berupa black shale dan coally shale di bagian atas seam A20 ini menunjukkan lingkungan pengendapan reduksi dimana proses sedimentasi berlangsung secara berangsur dan lambat. Keberadaan parting pada seam A20 ini dipengaruhi langsung oleh naik turunya air laut yang menunjukkan perbedaan dalam kondisi pada saat akumulasi material (Westoll dalam Murchison, 1968). Naik turunya air laut yang mempengaruhi sedimentasi gambut mengakibatkan tercampurnya material lain non karbon yang mengakibatkan batubara tidak bersih. Hal ini mengakibatkan nilai $\mathrm{CV}$ di bagian floor seam A20 di titik bor KP2N-397 dan KP2N-380 rendah.

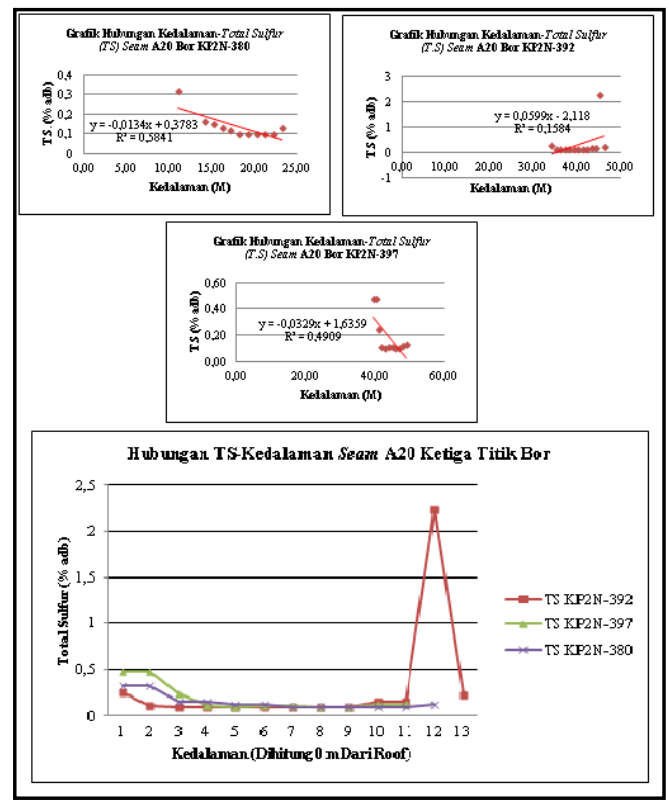

Gambar 3. Grafik Hubungan Total Sulfur Kedalaman Seam A20 Grafik pada tiap Bor dan Gabungan Ketiga Bor

Grafik hubungan kedalaman dengan total sulfur batubara seam A20 tampak bahwa trendline TS terhadap kedalaman di kedua titik bor KP2N-380 dan KP2N-397 memperlihatkan semakin dalam batubara 
maka TS semakin kecil. Hasil analisis statistik diperoleh bahwa di kedua titik bor mempunyai hubungan yang kuat sampai sangat kuat dan signifikan berupa menurunnya TS seiring semakin dalam letak batubara seam A20. Artinya menurunnya TS ditentukan oleh kedalaman batubara seam A20 sebesar $67 \%$ di titik bor KP2N 380 dan $49.1 \%$ di titik bor KP2N 397.

Adanya hubungan secara langsung antara penurunan TS dan semakin dalamnya seam A20 di titik bor KP2N 380 dan KP2N 397 dipengaruhi oleh roof dari lapisan batubara seam A20 yang berupa perselingan coally shale dan black shale merupakan batuan yang diendapkan di lingkungan swamp (rawa) pada Transitional Lower Delta Plain yang mengalami transgresi yang masih berasosiasi dengan lingkungan marine sulfur berkembang baik.

Grafik Hubungan TS-Kedalaman Seam A20 Ketiga Titik Bor dengan nilai ratarata TS di ketiga titik bor hampir sama sehingga kurva ketiga titik bor hampir berhimpit. Perbedaan nilai TS kedua titik bor dijumpai di kedalaman 39.5 - 40.93 di titik bor KP2N-397 dan $11.10-11.58 \mathrm{~m}$ di titik bor KP2N-380. Anomali nilai TS di kedalaman di kedua titik bor tersebut di atas diakibatkan karena melimpahnya kehadiran plant remain dalam black shale dan coally shale pada roof Seam A20. Kandungan plant remain dalam blackshale ataupun coally shale pada roof seam A20 dapat menaikan kandungan total sulfur batubara. Pada saat pembusukan sulfur tidak ikut membusuk dan tersisa hingga pada saat terbentuknya batubara (Stach's, 1982), kehadiran plant remain pada bagian atas seam A20 menaikan kandungan sulfur total.
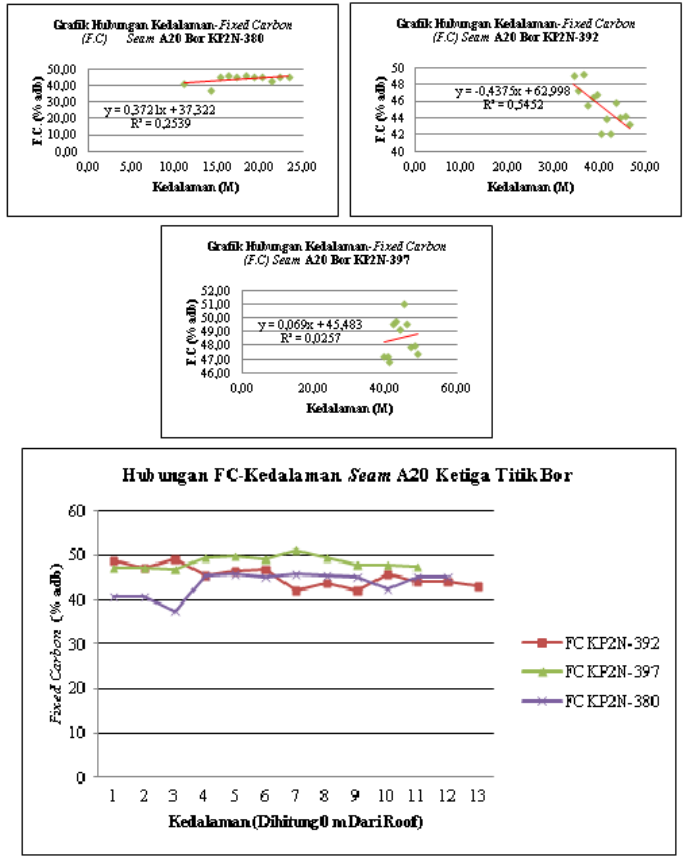

Gambar 4. Grafik Hubungan Fixed CarbonKedalaman Seam A20 Grafik pada tiap Bor dan Gabungan Ketiga Bor

FC ini didifinisikan sebagai material yang tersusun setelah berkurangnya moisture (M), volatile matter (VM) dan ash. Secara umum kandungan $\mathrm{FC}$ akan sebanding dengan kandungan $\mathrm{CV}$, semakin besar kandungan FC maka akan diikuti dengan kenaikan kandungan $\mathrm{CV}$.

Grafik hubungan kedalaman dengan fixed carbon batubara seam A20 tampak bahwa trendline $\mathrm{FC}$ pada bor KP2N-380 naik seiring kedalamnya dengan kontribusi kedalaman sebesar 33\%. Hasil analisis statistik data bor KP2N-380 terdapat hubungan yang kuat dan tidak signifikan secara langsung pada kenaikan FC seiring semakin dalamnya batubara seam A20. Hubungan langsung yang kuat antara naiknya kandungan FC dengan kedalaman seam A20 ini dikarenakan turunya kandungan $\mathrm{M}$ dan ash seiring kedalaman pada bor KP2N-380. Hal ini dapat dilihat dari grafik hubungan $\mathrm{M}$ dan ash terhadap kedalaman, dimana $\mathrm{M}$ dan ash menurun seiring kedalaman seam A20 di titik bor KP2N-380. 

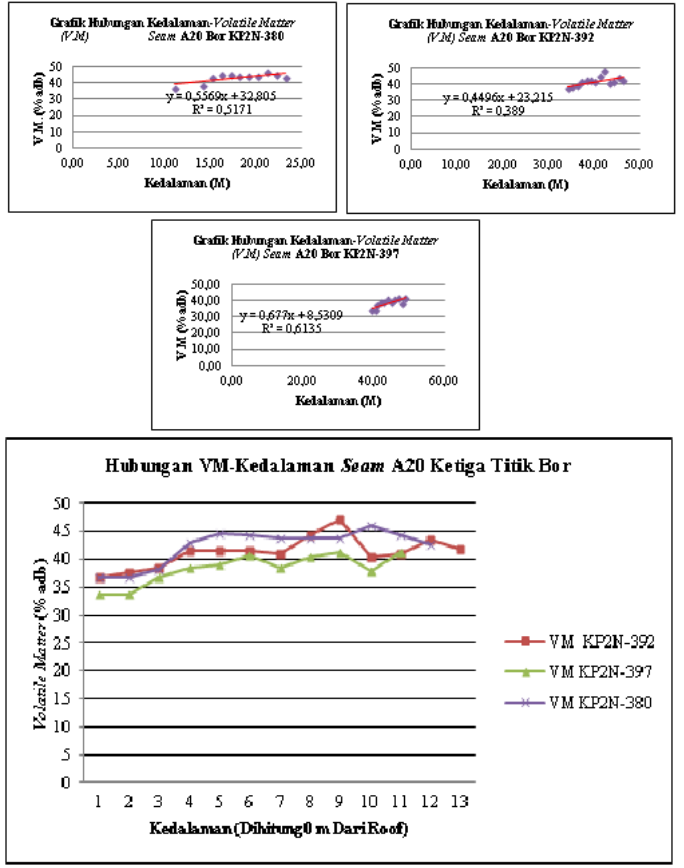

Gambar 5. Grafik Hubungan Volatil MaterKedalaman Seam A20 Grafik pada tiap Bor dan Gabungan Ketiga Bor

Grafik hubungan kedalaman dengan volatile matter batubara seam A20 memperlihatkan trendline $\mathrm{VM}$ versus kedalaman di ketiga titik bor KP2N-380, KP2N-392 dan KP2N-397 menunjukan VM semakin besar seiring kedalamannya. Hasil analisis statistik dari data ketiga titik bor tersebut menunjukan hubungan langsung yang kuat dan signifikan antara peningkatan VM dengan kedalaman batubara seam A20. Kontribusi kedalaman terhadap VM adalah: KP2N-380 sebesar $62 \%$, di titik bor KP2N-392 sebesar 38.9\% dan di titik bor KP2N-397 sebesar 61.3\%. Hal tersebut membuktikan kenaikan VM ini secara langsung ditentukan oleh kedalaman batubara seam A20.

Grafik Hubungan VM-Kedalaman Seam A20 ketiga titik bor terlihat anomali tingginya nilai VM dijumpai di kedalaman 41.26 - $42.26 \mathrm{~m}$ di titik bor KP2N-392. Tingginya kandungan VM di titik bor KP2N-392 di kedalaman tersebut dikarenakan turunya kandungan $\mathrm{M}$ dan ash seiring dalamnya seam A20 di titik bor KP2N-392. Hal ini dapat dilihat dari grafik hubungan $\mathrm{M}$ dan ash terhadap kedalaman dimana kandungan $\mathrm{M}$ dan ash menurun seiring dalamnya seam A20 di titik bor KP2N-392.
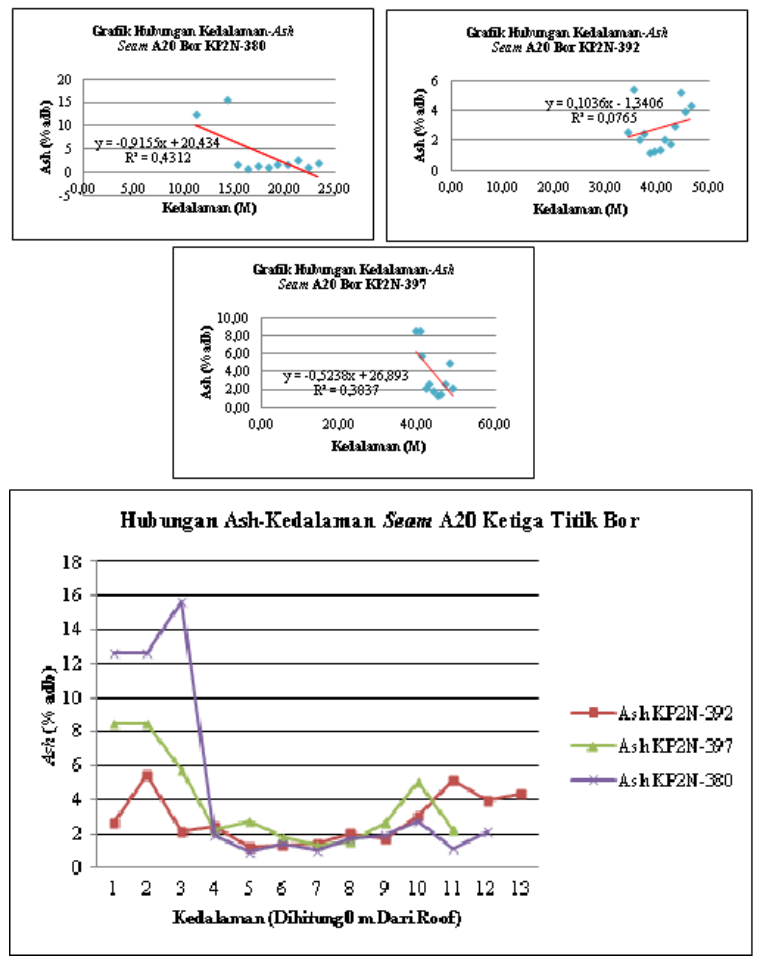

Gambar 6. Grafik Hubungan Ash -Kedalaman Seam A20 Grafik pada tiap Bor dan Gabungan Ketiga Bor

Grafik hubungan kedalaman dengan ash batubara seam A20 tampak bahwa trendline ash terhadap kedalaman di kedua titik bor KP2N-380 dan KP2N-397 memperlihatkan semakin dalam batubara maka ash semakin kecil. Hasil analisis statistik diperoleh bahwa di kedua titik bor KP2N-380 dan KP2N-397 ada hubungan yang kuat dan signifikan secara langsung bahwa turunya ash seiring semakin dalamnya batubara seam A20. Kontribusi kedalaman terhadap naiknya kandungan ash di titik bor KP2N-380 sebesar 53\% dan di titik bor KP2N-397 sebesar 38.4\%. Artinya bahwa penurunan ash ini secara langsung ditentukan oleh kedalaman batubara seam A20. Secara umum semakin meningkat VM maka ash juga semakin meningkat. Pada daerah penelitian terjadi anomali dimana VM meningkat tetapi kandungan ash menurun. Semakin dalamnya posisi batubara seam A20 ini 
berhubungan dengan proses regresi yang terjadi saat itu. Lingkungan pengendapan seam A20 yang berupa rawa berangsur ke arah Lower Delta Plan (Candra Prastyani, 2004) menunjukkan terjadinya proses regresi.
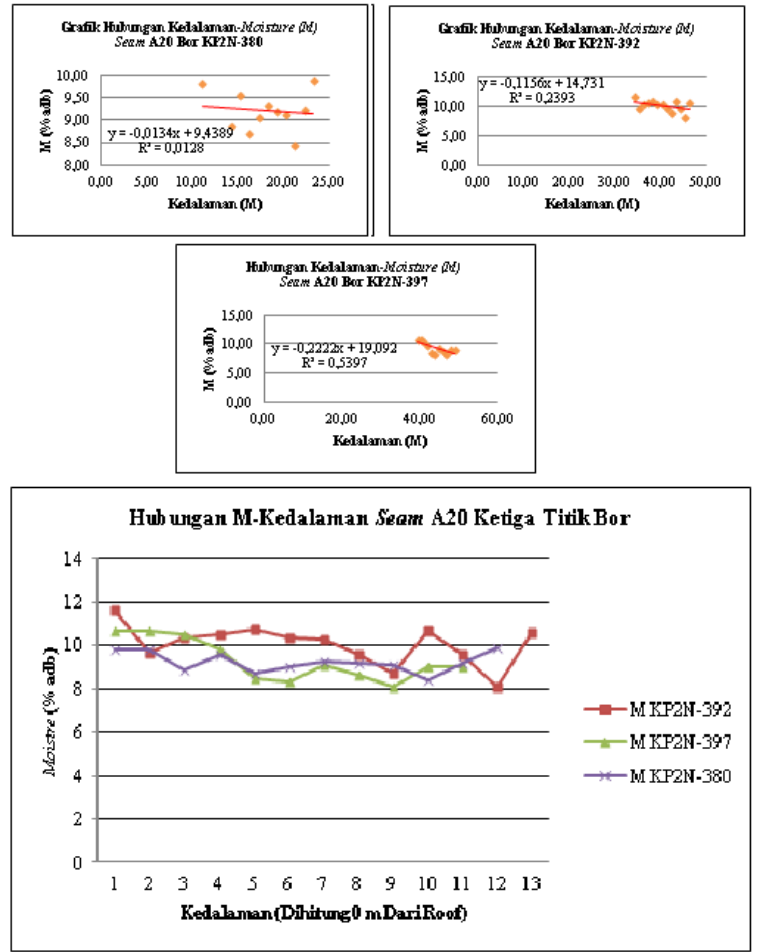

Gambar 7. Grafik Hubungan Moisture -

Kedalaman Seam A20 Grafik pada tiap Bor dan Gabungan Ketiga Bor

Grafik hubungan kedalaman dengan moisture batubara seam A20 tampak bahwa trendline $\mathrm{M}$ terhadap kedalaman di ketiga titik bor KP2N-380, KP2N-392 dan KP2N-397 memperlihatkan semakin dalam posisi batubara maka M semakin kecil. Hasil analisis statistik diperoleh bahwa di titik bor KP2N-380 tidak ada hubungan secara langsung dan tidak signifikan bahwa turunnya kandungan $\mathrm{M}$ dipengaruhi semakin dalamnya posisi batubara seam A20. Kontribusi kedalaman terhadap menurunya kandungan $\mathrm{M}$ pada titik bor KP2N-380 hanya sebesar 8\%. Menurunya kandungan $\mathrm{M}$ seiring makin dalamnya seam A20 ini lebih dikarenakan naiknya kandungan FC dan VM serta menurunya kandungan ash. Hal ini dikarenakan FC sebagai material yang tersusun setelah berkurangnya moisture (M), volatile matter (VM) dan ash dalam seam A20.

Hasil analisis statistik diperoleh bahwa di titik bor KP2N-392 dan KP2N-397 ada hubungan kuat secara langsung bahwa turunnya kandungan $\mathrm{M}$ dipengaruhi semakin dalamnya batubara seam A20. Kedalaman memberikan kontribusi terhadap menurunya $\mathrm{M}$ sebesar $23.8 \%$ di titik bor KP2N-392 dan $54 \%$ di titik bor KP2N-397.

Tabel Hasil Intrepretasi Statistik Hubungan Kualitas Batubara Total Terhadap Kedalaman Seam A20

\begin{tabular}{|c|c|c|c|c|}
\hline $\begin{array}{c}\mathrm{BO} \\
\mathrm{R}\end{array}$ & Q & $\begin{array}{l}\text { COE. CORR } \\
\left.\text { (Sig. } \text { F }_{\text {Change }}\right)\end{array}$ & $\begin{array}{c}\text { CTR } \\
\left(\mathrm{R}_{\text {Square }}\right)\end{array}$ & $\begin{array}{c}\text { INTE } \\
\text { PRETASI }\end{array}$ \\
\hline 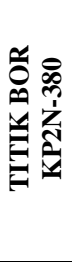 & $\begin{array}{l}C V \\
T S \\
F C \\
V \\
M \\
A s \\
h \\
M\end{array}$ & 0.020 & $84.90 \%$ & $\begin{array}{c}\text { Berhubungan } \\
\text { sangat kuat } \\
\text { dan signifikan }\end{array}$ \\
\hline 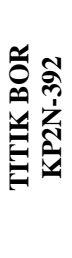 & $\begin{array}{l}C V \\
T S \\
F C \\
V \\
M \\
A s \\
h \\
M\end{array}$ & 0.022 & $86.10 \%$ & $\begin{array}{c}\text { Berhubungan } \\
\text { sangat kuat } \\
\text { dan signifikan }\end{array}$ \\
\hline
\end{tabular}

Ket :

$Q=$ Quality, $C O R=$ CORRELATION,$C T R=C O N T R I B U T I O N$ $B S K=$ Berhubungan sangat Kuat BK = Berhubunngan Kuat, $T B=$ Tidak Berhubungan, $S=$ Signifikan, $T S=$ Tidak Signifikan.

Adanya hubungan yang kuat dan signifikan secara langsung di kedua titik bor KP2N-380 dan KP2N-397 bahwa meningkatnya

$\mathrm{CV}$ seiring bertambahnya kedalaman seam A20 dikarenakan overburden pressure. Overburden Pressure diakibatkan oleh pengaruh pembebanan lapisan overburden terhadap seam A20 saat pembentukan batubara. Tebal Formasi Kampung Baru yang mencapai $900 \mathrm{~m}$ dan Formasi Balikpapan Atas yang mencapai 3000 m sehingga tebal keseluruhan overburden yang menindih seam A20 sebesar 3900 m 
menimbulkan overburden stress

terhadap seam A20 sebesar :

$$
\mathrm{S}=\rho_{\mathrm{b}} \times(\mathrm{Z} / 10)
$$

$\mathrm{S}=2.31 \times(3900 / 10)=900.9 \mathrm{~kg} / \mathrm{cm}^{2}$ (atm).

Overburden stress (S) sebesar 900.9 $\mathrm{kg} / \mathrm{cm}^{2}>500 \mathrm{~kg} / \mathrm{cm}^{2}$ (syarat overburden stress bagi pembentukan batubara).

Overburden Pressure ini mengakibatkan moisture dalam batubara akan berkurang dan calorific value meningkat. Akibat overburden pressure ini menimbulkan panas sehingga terjadi devolatisation/pelepasan zat terbang (volatile matter) dari lapisan batubara.

\section{Kesimpulan}

Hasil analisis statistik hubungan masingmasing kualitas seam A20 (CV, TS, FC, $V M$, Ash dan $M$ ) terhadap kedalaman seam A20 dengan menggunakan korelasi dan regresi tunggal diperoleh setiap lokasi titik bor memberikan hasil yang fluktuatif. Besar pengaruh kedalaman terhadap masing-masing kualitas seam A20 sebagai berikut (1) di titik bor KP2N-380 : CV $57 \%$, TS $67 \%$, FC 33\%, VM 62\%, ash $53 \%$ dan M 8\%, (2) di titik bor KP2N-392 : CV $2.3 \%$, TS $15.8 \%$, FC 54.5\%, VM $38.9 \%$, ASH 7.6\% dan M 7.6\%, (3) di titik bor KP2N-397 : CV 53.3\%, TS 49.1, FC $2.6 \%$, VM $61.3 \%$, ASH $38.4 \%$ dan $\mathrm{M}$ $54 \%$.

Faktor Geologi Overburden pressure dan structural geology berpengaruh pada nilai $\mathrm{CV}$ dan VM, trangresi-regresi dan depositional Enviroment berpengaruh pada nilai ash, VM dan TS dan original coal composition yang mempengaruhi nilai FC.

\section{Saran}

Variasi penyebaran kualitas seam A20 secara vertikal dapat membantu untuk strategi eksploitasi selanjutnya. Sebagai contoh hasil analisa statistik diatas menunjukkan kandungan TS dan ash dalam seam A20 di bagian atas dan bawah seam A20 kandungan TS dan ash meningkat. Sementara kandungan TS dan ash di bagian tengah seam A20 relatif konstan. Hal ini membantu dalam usaha blending batubara dalam satu seam antara bagian atas/bawah dengan bagian tengah atau blending dengan batubara lain untuk mendapatkan batubara dengan kualitas tertentu .

\section{Daftar Pustaka}

Arwita dan Sinarindraweda, 2003, Geologi Daerah Karangmulya dan Sekitarnya Kecamatan Samarinda Ulu Kotamadya Samarinda Kalimantan Timur, Skripsi Jurusan Teknik Geologi UPN "Veteran" Yogyakarta, Unpublish.

, 1983, Coal Quality, American Society of Test Material, ASTM.

Budi Prayitno, 2011, Kontrol Geologi dan Analisis Kualitas Batubara Daerah Beanhas dan Sekitarnya Kecamatan Muara Wahau Kutai, Jurnal Ilmiah Magister Teknik Geologi UPN "Veteran" Vol. 4, Yogyakarta.

Braunstein, H., M., 1981, Enviromenttal, Health and Control Aspects of Coal ,Conversion-An Information Overview, Vol. 1, Arbor Science Publisher.

Candra Prastiyani, 2004, Kendali Geologi Terhadap Kualitas Batubara Seam A2 dan Seam A4 Konsesi P.T. Bukit Baiduri Energi Samarinda, Skripsi Jurusan Teknik Geologi UPN "Veteran”, Unpublish.

Cook. A.C., 1999, Coal Geology and Coal Properties, Keiraville Konsultants, Australia, P. 68-78 and 179-185.

Diessel, CFK., Coal-Bearing Depositional System, Springer-Verlag, Berlin, Hedelberg, 1992.

Heryanto R, 2009, Karakteristik dan

Lingkungan Pengendapan Batubara Formasi Tanjung di daerah Binuang dan sekitarnya Kalimantan Selatan, Jurnal Geologi Indonesia Vol. 4 No. 4 Desember 2009, Bandung. 
Horne, J.C., et. Al., Depositional Models in Coal Exploration and Mining Planning in Appalachian Region, AAPG Bulletin 62 p. 2379-2411, America

Komang Anggayana, Agus Haris Widayat, 2007, Interpretasi Fasies/Lingkungan Pengendapan Batubara dan Variasi Sulfur untuk Rekomendasi Strategi Eksplorasi Kasus: Seam $R$, daerah Lati, SubCekungan Berau, Cekungan Tarakan, Jurnal Geoaplika (2007) Volume 2, Nomor 1 , hal. $35-52$.

Kusnama, 2008, Batubara Formasi Warukin di Daerah Sampit dan Sekitarnya, Jurnal Geologi Indonesia Volume 3, hal. 11-22.

Murchison D and Westoll T.S., 1968, Coal and Coal Bearing Strata, Edinburgh and London

Rainir Dhadar J, Eksplorasi Endapan Bahan Galian, GSB Bandung.

Ridwan dan Sunarto, 2007, Pengantar Statistika, Bandung, AlFABETA.

Rifin Masri, 1999, Kualitas (Mutu) Batubara, Direktorat Jendral Pertambangan Umum Puslitbang Teknologi Mineral, Bandung.

Rose, R dan Hartono P., 1978, Geological Evolution of The Tertiary Kutai-Melawi Basin, Kalimantan, Indonesia. Proceeding of the $7^{\text {th }}$ Annual Convention, IPA, hal. 225-251.
Samuel and Muchsin, S., 1975, Stratigraphy and Sedimentation in The Kutai Basin Kalimantan, Proceding of the Fourth Annual Convetion, Indonesia Petroleum Assoc., p.27-29.

Siemers, 1994, Mahakam Delta, Field Seminar on The Sedimentology and Sequence Stratigraphy of Modern and Ancient Mahakam Fluvial, Deltaic and Shelf Deposits, American Association of Petroleum Geologist, America.

Stach E., Teichmuller M., dkk., 1982, Coal Petrology, Gebruder Borntraeger, Berlin.

Supriatna S. \& Rustandi, E., 1995, Geologi Daerah Samarinda dan Sekitarnya Kalimantan Timur, Pusat Penelitian dan Pengembangan Geologi, Bandung.

Taylor GH, Teichmuller M, Davis A., Diessel CFK, Little R., Robert P., Organic Petrology, Gebruder Borntraeger, Berlin, Stuttgart, 1998.

Van Zuidam, R.A., 1983, Guide to Geomorphic Areal Photography Interpretation and Mapping, Enschede 325 p.

Wahyono dan Sidarta, 2001, Hubungan Struktur Geologi dan Proses Pembatubaraan di Daerah Talondo Kalumpang Mamaju Sulawesi Selatan, Majalah Geologi Indonesia, Volome 16, hal. 146-159. 